2007s-28

\title{
The Survival and Success of Canadian Penny Stock IPOs
}

\author{
Cécile Carpentier, Jean-Marc Suret
}

\section{Série Scientifique \\ Scientific Series}

\begin{abstract}
Montréal
Mars 2009

(Ce document est une mise à jour du cahier scientifique 2007s-28 paru en novembre 2007 sous le titre « The Survival and Success of Penny Stock IPOs: Canadian Evidence »
\end{abstract}

(C) 2009 Cécile Carpentier, Jean-Marc Suret. Tous droits réservés. All rights reserved. Reproduction partielle permise avec citation du document source, incluant la notice (C).

Short sections may be quoted without explicit permission, if full credit, including (C) notice, is given to the source.
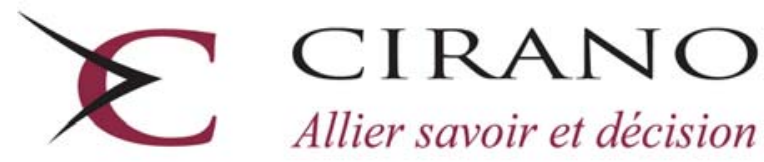

Allier savoir et décision

Centre interuniversitaire de recherche en analyse des organisations 


\section{CIRANO}

Le CIRANO est un organisme sans but lucratif constitué en vertu de la Loi des compagnies du Québec. Le financement de son infrastructure et de ses activités de recherche provient des cotisations de ses organisations-membres, d'une subvention d’infrastructure du Ministère du Développement économique et régional et de la Recherche, de même que des subventions et mandats obtenus par ses équipes de recherche.

CIRANO is a private non-profit organization incorporated under the Québec Companies Act. Its infrastructure and research activities are funded through fees paid by member organizations, an infrastructure grant from the Ministère du Développement économique et régional et de la Recherche, and grants and research mandates obtained by its research teams.

\section{Les partenaires du CIRANO}

\section{Partenaire majeur}

Ministère du Développement économique, de l’Innovation et de l’Exportation

\section{Partenaires corporatifs}

Banque de développement du Canada

Banque du Canada

Banque Laurentienne du Canada

Banque Nationale du Canada

Banque Royale du Canada

Banque Scotia

Bell Canada

BMO Groupe financier

Caisse de dépôt et placement du Québec

DMR

Fédération des caisses Desjardins du Québec

Gaz de France

Gaz Métro

Hydro-Québec

Industrie Canada

Investissements PSP

Ministère des Finances du Québec

Power Corporation du Canada

Raymond Chabot Grant Thornton

Rio Tinto Alcan

State Street Global Advisors

Transat A.T.

Ville de Montréal

\section{Partenaires universitaires}

École Polytechnique de Montréal

HEC Montréal

McGill University

Université Concordia

Université de Montréal

Université de Sherbrooke

Université du Québec

Université du Québec à Montréal

Université Laval

Le CIRANO collabore avec de nombreux centres et chaires de recherche universitaires dont on peut consulter la liste sur son site web.

Les cahiers de la série scientifique (CS) visent à rendre accessibles des résultats de recherche effectuée au CIRANO afin de susciter échanges et commentaires. Ces cahiers sont écrits dans le style des publications scientifiques. Les idées et les opinions émises sont sous l'unique responsabilité des auteurs et ne représentent pas nécessairement les positions du CIRANO ou de ses partenaires.

This paper presents research carried out at CIRANO and aims at encouraging discussion and comment. The observations and viewpoints expressed are the sole responsibility of the authors. They do not necessarily represent positions of CIRANO or its partners. 


\title{
The Survival and Success of Canadian Penny Stock IPOs*
}

\author{
Cécile Carpentier ${ }^{\dagger}$, Jean-Marc Suret ${ }^{\ddagger}$
}

\begin{abstract}
Résumé / Abstract
Nous analysons la survie et le succès d'un grand échantillon d'émissions initiales d'actions cotées en cents (les penny stocks), lancées majoritairement par des entreprises de petite taille non rentables entre 1986 et 2003. Le taux d'échec de ces émissions est moindre que celui observé aux États-Unis pour des opérations de plus grande taille. Ceci peut découler de règles de radiation plus souples et de la capacité du marché boursier canadien à refinancer des entreprises qui ne dégagent pas de bénéfices. La survie des émetteurs est significativement liée à leurs caractéristiques lors de l'émission initiale et au niveau de normes minimales qu'ils satisfont au moment de l'entrée en Bourse. L'implication d'intermédiaires de bonne réputation lors de l'émission modère cet effet. Le taux de succès, défini ici comme l'inscription sur une Bourse de niveau supérieur, est peu lié aux caractéristiques financières qui prévalent lors de l'émission. Le Canada semble avoir développé une stratégie particulière pour financer des entreprises de petite taille mais la probabilité d'échec des entreprises qui entrent en Bourse avant de rapporter des revenus reste très importante.
\end{abstract}

Mots clés : Financement des petites entreprises, émissions initiales d'actions, survie, succès, normes minimales d'entrée en Bourse.

We analyze the survival and success of a large sample of Canadian penny stock initial public offerings (IPOs), launched mostly by small and unprofitable firms from 1986 to 2003. The failure rate of these IPOs is lower than the one observed in the U.S. for larger IPOs, probably because of lax delisting rules and the market's capacity to refinance non-profitable firms. The survival of new issuers is significantly associated with their characteristics at the IPO and with the level of initial listing requirement they meet. The involvement of reputable intermediaries in the IPO process mitigates this effect. Success, estimated by the graduation to a senior exchange, is not linked to the financial conditions at the IPO. Overall, Canada seems to have developed a particular strategy to finance the growth of small firms even if the propensity to fail of firms listed at a pre-revenue stage is indeed very high.

Keywords: small business finance, initial public offering, survival, success, minimum listing requirements.

Codes JEL : G38, G32, K22

\footnotetext{
* The authors thank the Fonds réservé de l’Autorité des marchés financiers du Québec (the "Autorité") and the Social Sciences and Humanities Research Council (SSHRC) of Canada for financial support. The authors are grateful for comments from two anonymous reviewers, Michel Levasseur, Eric de Bodt, Janet Smith and participants at the Canadian Law and Economics Association annual meeting in Toronto (September 2007), the ESC/ESA seminar in Lille (December 2007), the AFFI Finance International Meeting in Paris (December 2007), the Oxford EFMA IPO symposium (April 2008) and the AFFI International Conference in Lille (May 2008).

Forthcoming in Small Business Economics.

${ }^{\dagger}$ Cécile Carpentier, professor at Laval University and CIRANO Fellow.

‡ Jean-Marc Suret, professor at Laval University and CIRANO Fellow. Email: Jean-Marc.Suret@fsa.ulaval.ca.
} 


\section{INTRODUCTION}

In this paper, we attempt to determine the economic consequences of enabling small and unprofitable firms to access the stock market. For regulators, the question translates into the optimal level of minimum listing requirements, which define the conditions a company must meet to be initially listed on an exchange. Stringent requirements limit the capacity of small firms to be publicly funded. More lenient requirements reduce investor protection and market quality, while enabling smaller and unprofitable firms to access the market. In the last twenty years, the changes in minimum listing requirements observed in several countries illustrate the quest for equilibrium of these effects.

Small and emerging companies are often considered financially constrained (Samitas and Kenourgios 2005). Accessing the stock market through an initial public offering (IPO) is a way to obviate this financing constraint (Kim 1999). The desire to ease the financing of small firms led to the creation of several "new" (or junior) markets that applied more lenient listing rules than the regular exchanges. This approach has been questioned following the collapse of these markets in Europe. In the U.S., investor protection was the main reason put forth to justify the Penny Stock Reform Act (PSRA) in 1990. This Act restricted IPOs that were priced below US\$5 (Beatty and Kadiyala 2003). However, several exchanges, including the NASDAQ, lowered their listing requirements significantly during the technology bubble (Harris 2006). The new standard allowed the entry of a large cohort of unprofitable firms that ultimately rose and fell with the NASDAQ bubble of the late 1990s (Klein and Mohanram 2006). Following the burst of the technology bubble, some countries limited the discretion of the exchanges to set the minimum listing requirements. The Securities Exchange Commission (SEC) froze these requirements in 2005 and the U.K. Listing Authority was transferred to the Financial Services Authority in 2000.

Very few studies have attempted to document the optimal level of the requirements. Empirical evidence of the consequences of the listing standard is very scarce, and the desirability and efficacy of regulation through listing requirements is still an open and important question. According to Bottazzi and Da Rin (2005, p.28) "there is an obvious need to evaluate how existing rules perform, in terms of selecting valuable companies.” Klein and Mohanram (2006) underline that there is little evidence on the economic ramifications of stock market minimum listing requirements. This lack of empirical evidence is the first motivation of our research. 
The reduction in initial listing requirements during the ' 90 s had enabled a growing number of firms to list at an early development stage, both in the U.S. (Fama and French 2004) and on the new markets (Bottazzi and Da Rin 2005). However, mainly to prevent fraud and manipulation, none of the reductions in requirements has reached the level where very small and unprofitable firms were enabled to list following "penny stock IPOs.” ${ }^{1}$ The general opinion about IPO minimum size is expressed by Berger and Udell (1998, p.13): “a combination of informational opacity and issue costs will determine the size of firm for which a public offering becomes economically attractive. (...) A reasonable guess for the minimum assets size for entering this market would be about $\$ 10$ million.” As a result, regulation prohibits penny stock IPOs in most countries, despite the putative improvement in access to stock markets for small businesses. Nonetheless, the first recommendation of the Advisory Committee on Smaller Public Companies (SEC 2006) is to establish a system of scaled regulation for smaller public companies, if they qualify as microcap companies. In the same vein, several academics and policy makers have argued that the securities regulation constrains the public financing of small businesses (Cohn 1999; Chiu 2004). Bottazzi and Da Rin (2005) assert that allowing small companies to go public confers several advantages. In this context, we contend that the reexamination of the economic effect of listing requirements should include the analysis of the economic effect of prohibiting small firms from issuing penny stock IPOs. The lack of evidence regarding the listings of very small companies and the timeliness of this topic constitute the second justification of our paper.

Our general hypothesis is that the class of minimum listing requirements in which the firm is situated at the IPO is linked to its survival and success rates. To analyze the effect of listing requirements on the outcome of the IPO process, we use a large sample of 2,373 IPOs, collected from 1986 to 2003 in a country where the minimum listing requirements are so low that we can consider that every company could be listed. For the last twenty years, more than $45 \%$ of issuers report no revenues, $71 \%$ report negative earnings and the median gross proceeds of IPOs is CAN\$800,000. According to the U.S. limit of US\$5, 86.01\% of IPOs are penny stock IPOs

\footnotetext{
${ }^{1}$ The definition of a penny stock has been debated for years. In the U.S., a penny stock IPO is priced under US\$5 and is generally traded on over-the-counter markets such as the Over the Counter Bulletin Board Exchange (OTCBB). Penny stocks are issued by very small firms, which are generally defined as microcap firms. In Bradley et al. (2006) penny stock IPOs have a mean gross proceeds of US\$5.7 million. Firms listed on the OTCBB with a stock price lower than US\$5 (deciles one to six) have a market value ranging from US\$370,000 to US\$7.76 million, from 1996 to 2000 (Luft and Levine 2004). Accordingly, we consider that penny stocks can be characterized by a market value lower than US\$10 million.
} 
(2,041 out of 2,373). Canada, where the bulk of new listings are penny stock IPOs by small and non-profitable firms, presents a unique opportunity to analyze the effect of listing requirements. In this paper, we analyze the consequences of applying more stringent hypothetical initial listing requirements on the survival and success of newly listed companies. We examine both the probability and the time to failure and success, taking into consideration the classical control variables. We make several contributions to the literature. First, we propose the first large scale analysis of the survival of penny stock IPOs, covering 20 years. Bradley et al. (2006) analyze a small sample (251) of these issues over a short period of time (1990-98). Our sample mainly consists of small firms without revenues, a situation that has never been analyzed. Second, we do not limit our study to the failure rates; rather, we provide empirical evidence of the probability and determinants of success. Audretsch and Lehmann (2005) propose that the ability to survive over time be used as an indicator of success. We refine this measure and define success by the firm's accessing a more senior stock exchange that applies more restrictive listing requirements: a process known as "graduation." 2 This criterion is commonly used by the exchange itself as a gauge of success. Third, our paper contributes to the scarce literature devoted to the economic effects of minimum listing requirements. Given the strong interest in junior markets in Europe, this question is intriguing for both rule-makers and academics. Lastly, we document the performance of a public market that competes with conventional venture capital, a strategy that can provide significant insight for policy makers.

The next section discusses the specific features of the Canadian market in terms of listing requirements, institutional involvement, financing possibilities and success of listed firms. Section 2 surveys the previous results and states our hypotheses. Section 3 discusses data sources and stylized facts. We present the method and our results in section 4.

\section{1) DisTinCTIVE CHARACTERISTICS OF THE CANADIAN MARKET}

There are two main recognized stock exchanges in Canada: Toronto Stock Exchange (TSX), and TSX Venture Exchange (TSXV). TSXV and its predecessors are junior markets. The Canadian market is composed of a few large-sized companies, generally cross-listed in the U.S., and numerous small firms. This situation results in part from very lax listing requirements. For a

\footnotetext{
${ }^{2}$ In Canada, firms graduate when they move their listing from the junior exchange (TSXV) to the main exchange, TSX. However, as TSX is itself a junior market relative to the U.S. main exchanges, a firm listed on TSX can graduate to the NYSE.
} 
listing on Tier 2 of TSXV, a firm must meet the following conditions: stock price over CAN\$0.15 and post-IPO net tangible assets and market capitalization higher than CAN\$500,000. TSXV has no requirements relative to issuers' profitability; it simply stipulates sufficient working capital for 12 months of operations. The atypical situation of the Canadian market can be illustrated by the comparison of the minimum requirements for size (CAN\$0.5 million) with the key values of new listings on other junior markets. These markets can be divided in two groups: either they use quantitative listing requirements or they use a principles-based approach, whereby firms need to hire a sponsor to list. In the first group, IPOs on the Neuer Markt in Germany had average gross proceeds (pre-IPO equity) equivalent to CAN\$99.80 (20.45) million from 1997 to 2002 (Burghof and Hunger 2004). Corresponding median values for all new markets in Europe, from 1996 to 2001, were CAN\$74.99 (6.51) million (Bottazzi and Da Rin 2005). In the second group, the mean gross proceeds (market capitalization) are CAN\$15 (31.57) million for the Alternative Investment Market in London (AIM) and CAN\$28.88 (85.53) million for First North, in the Nordic countries (Carpentier et al. 2009). The smaller issues are then detected on the AIM, and they represent 19 times the median gross proceeds of the IPOs analyzed in this paper.

The small size of the new issues and their lack of liquidity in the after-market prevent institutional investors from playing a significant role in all but the largest Canadian IPOs. Detailed statistics on shareholding are not available, but the median post-IPO capitalization is below CAN\$2 million. Such a value is too small to permit institutional investments, generally limited to the 60 most heavily capitalized Canadian stocks. Accordingly, the IPO Canadian market is largely driven by individual investors. The market is also characterized by vibrant private placement activity by public firms (Carpentier et al. 2008). Most of the private placements are raised by firms at a pre-revenue stage.

As an incubator for small firms, TSXV encourages the most successful firms to graduate to the main board. Similarly, successful TSX firms generally cross-list in the U.S. Canadian managers are highly aware of several advantages of listing abroad (Mittoo 1992). This situation explains why more than 510 Canadian companies cross-listed in the U.S. from 1986 to 2006 Lastly, the Canadian stock market is characterized by the large relative weight of natural resources companies. The Energy (Oil \& Gas) sector accounts for 13\% of companies listed on TSXV and 25.22\% of market capitalization. Corresponding values for the Materials (Mining) 
sector are $46.74 \%$ and $50.70 \%$. Collectively, natural resources (Energy and Materials) companies account for $27.36 \%$ of companies listed on TSX and $38.07 \%$ of its capitalization.

\section{2) Previous studies and hypotheses}

\section{1) REVIEW OF THE LITERATURE}

The empirical literature devoted to the fate of newly listed firms is limited to a dozen papers, based mainly on U.S. samples. With a few exceptions, this literature concerns large IPOs, which predominate in the U.S. As mentioned by Bradley et al. (2006, p.25) "IPO researchers routinely screen out lower-priced issues and, as a consequence, penny stock IPOs have been largely ignored in the IPO literature." Seguin and Smoller (1997) also observe that by explicitly eliminating penny stock IPOs from their samples, researchers might have overlooked an interesting facet of IPO behavior. Even when researchers do not formally exclude penny stocks from their sample of new listings, the characteristics of the population eliminate small firms. In the U.S., IPOs priced under US\$5 became rare after the PSRA. Audretsch and Lehmann (2005) analyze the Neuer Markt, where the IPOs reach a median gross proceeds equivalent to CAN\$100 million. They cannot be considered penny stocks. ${ }^{3}$ Similarly, Jain et al. (2008) use 160 Internet IPO firms, with a mean issue price (gross proceeds) of US\$16.12 (US\$99.48 million); these IPOs cannot be considered penny stock IPOs either.

Bradley et al. (2006) provide recent evidence regarding penny stock IPOs over the 1990-1998 period. They report a five-year delisting rate of $51.4 \%$, compared with $14.3 \%$ for conventional IPOs. Their analysis of underwriters suggests that market manipulation and/or fraud might explain a substantial part of the long-run underperformance of penny stock IPOs. Weber and Willenborg (2003) focus on the role of auditors in microcap IPOs, using a sample of firms listed on the NASDAQ in 1993 and 1994. They report a delisting rate of 25.3\% after 4 years. Based on pre-PSRA data (1974-1988), Seguin and Smoller (1997) evidence that low-priced stocks are more likely to leave the NASDAQ for negative reasons than high-priced stocks (37.4\% versus $17.4 \%$ after 5 years). Complementary results, based on a small sample of 59 restaurants listed from 1990 to 1996, are provided by Dalbor and Sullivan (2005).

\footnotetext{
${ }^{3}$ According to our definition in Note 1.
} 
Previous studies of the large IPOs exhibit considerable variation in the estimated proportions of failure. ${ }^{4}$ The rates reported in the U.S. after 5 years range from 11.1\% (Schultz 1993; Bhabra and Pettway 2003) to $14.3 \%$ (Bradley et al., 2006), and even $25.5 \%$ to $29.9 \%$, when acquired firms are considered as non-surviving (Jain and Kini 2000). Demers and Joos (2007) evidence large differences between the non-survival rates of high tech vs. non-high-tech firms (16.7\% vs. 9.2\%). In the Internet sector, the failure rate is estimated at $34.1 \%$ by van der Goot et al. (2007). Using a longer perspective of 10 years, Fama and French (2004) report failure rates of 40.5\% and 12.2\% respectively for issuers under/over the median size of the NYSE. For an older period of analysis (1976 to 1984), Hensler et al. (1997) report a huge rate of non-survival of 55.1\% after 10 years. This proportion includes the acquired firms. Previous results indicate that the size and the technological dimension of the issuers partly explain the survival probability.

Although most of the studies in this area are devoted to failures, it is worth taking into consideration the success of newly listed companies. Optimal listing requirements should allow every firm with a reasonable chance of success to list and delay the access for the companies that present a high risk of failure. The growth of new ventures has attracted the attention of several researchers (Gilbert et al. 2006), but very few works have explored the definitions and conditions of success of newly listed companies. For instance, venture capital (VC)-backed firms generate sales and assets more quickly (Coakley et al. 2007). According to Field and Lowry (2005), IPOs with greater institutional shareholding outperform those with lesser institutional shareholding. However, only two papers are dedicated to explaining the success of newly listed firms. In the Internet sector, Jain et al. (2008) find that an increase in firm age, number of employees, pre-IPO investor demand and governance considerations are associated with a higher probability of reaching post-IPO profitability. Audretsch and Lehmann (2005) evidence the specificities of knowledge-based companies. The influence of executive ownership on performance, estimated by the capacity to survive, disappears when the indicators of knowledge are added to the model. Clearly, knowledge of the factors underlying the success of small and pre-revenue stage IPOs is still limited

\footnotetext{
${ }^{4}$ In this field of research, the term "failure" is conventionally defined as the firm's inability to maintain its listing. The delisting is often associated with a bankruptcy, but also with all the situations where the firm is unable to maintain a financial situation that allows it to meet the ongoing listing requirements.
} 
A similar conclusion can be drawn regarding the influence of minimum listing requirements on the fate of newly listed companies. To our knowledge, there is only one study addressing this question (Klein and Mohanram, 2006). Using the specific period during which the firms could list on the NASDAQ according to two different sets of requirements, the authors show that firms that exceed the profitability requirements are less likely to delist.

\section{2) HYPOTHESES}

Our general hypothesis is that the class of minimum listing requirements in which the firm is situated at the IPO is linked to its survival and success propensity. ${ }^{5}$ Initial listing requirements generally refer to profitability, size, market capitalization and stock prices as main indicators. Previous empirical and theoretical works suggest that lowering the threshold for these quantities reduces the quality and survival of issuers. However, governance consideration and specialized intermediaries can mitigate this effect, as can several control variables. We consider that the factors associated positively with the propensity to fail are negatively linked with the propensity to succeed.

\subsection{1) Minimum listing requirements, survival and success}

Minimum listing requirements generally stipulate positive earnings. The requirement of reporting revenues before listing is implicit in the earnings requirements, and stock exchanges generally do not consider listing firms at a pre-revenue stage. Indeed, there are arguments against the listing of such growing companies. First, the failure rate of companies at a pre-revenue stage is high, and individual investors do not have the tools and abilities to correctly appraise such investments, which share many characteristics of private equity. Second, pre-revenue firms are generally financed by specialized intermediaries that are able to address information problems through screening, contracting and monitoring activities. As Giudici and Roosenboom (2004, p.IX) maintain, "stock market financing lacked the typical provisions such as active monitoring and covenants that are implemented by venture capitalists to protect their investments against information asymmetries and entrepreneurs' opportunism.” Accordingly, our first proposition is as follows:

\footnotetext{
${ }^{5}$ The propensity of newly listed firms to fail or succeed is estimated using rates of failure or success in some studies, whereas other researchers measure the time elapsed between the IPO and the event. We use both methods in this study.
} 
Proposition 1: The propensity of newly listed companies to fail (succeed) is significantly lower (higher) for firms that report revenues at the IPO time than for firms that list at a pre-revenue stage.

Firms with revenues but no earnings present the same risks and valuation problems as firms without revenues, but to a lesser extent. They therefore require external financing. Moreover, unprofitable firms find it more difficult to hire and retain high quality human resources, whose involvement seems to be critical in explaining newly listed companies' success. As evidenced by Klein and Mohanram (2006) we anticipate a larger failure rate and a lower success rate for this group of issuers than for profitable firms. Our second proposition is then:

Proposition 2: The propensity of newly listed companies to fail (succeed) is significantly lower (higher) for firms that report positive earnings at the listing time than for non-profitable firms.

Among profitable issuers, we predict that smaller ones have lower success rates and higher delisting probabilities than larger ones. Berger and Udell’s (1998 p.13) threshold of US\$10 million at the beginning of the ' 90 s can be translated into US\$18 million (CAN25\$ million), which is the level 2 requirement of NASDAQ. Accordingly, our third proposition is:

Proposition 3: The propensity of newly listed companies to fail (succeed) is significantly lower (higher) for profitable firms that report shareholders' equity over the threshold of CAN\$25 million than for smaller firms.

The variables defined previously are the main components of the minimum listing requirements. To translate these values into tractable categories of requirements, we define the status of each issue relative to hypothetical listing requirements. ${ }^{6}$ The first variable (NORM1) is given a value of 1 if the issuing company does not satisfy the minimum requirement of having revenues. NORM2 is 1 if the issuer has revenues but no positive earnings. Most of the new listing rules include a requirement for a track record of earnings. We consider that a firm is situated at level 3 (NORM3 $=1$ ) if the issuer has positive earnings but shareholders' equity lower than CAN\$25 million. Issuers that exceed this threshold are classified as level 4 (NORM4 = 1); they generally have sufficient characteristics at the issue time to list on NASDAQ. The summary of our previous propositions leads to our fourth proposition:

Proposition 4: The propensity of newly listed companies to fail or succeed is significantly linked to the level of initial listing requirements they meet.

\footnotetext{
${ }^{6}$ We do not refer to profitability ratios commonly used in U.S. studies because more than $70 \%$ of the new Canadian issuers exhibit a loss at IPO.
} 


\subsection{2) Governance and specialized intermediaries}

VC-backed IPOs generally exhibit better post-listing performance and survival probability (Chou et al. 2006). By filtering the ventures they finance, the venture capitalists (VCs) are able to select the best prospects. They remain involved in the newly listed firms for several months, owing to the rules prohibiting the sale of their shares. They can then continue their function of monitoring and consulting and thus have a positive effect on performance. The choice of a prestigious broker or auditor has generally been considered a positive signal, characterized by lower underpricing and better long-run performance, associated with a decrease in the asymmetry of information (Carter and Manaster 1990). The probability of survival is higher for issuers that hire a prestigious investment banker, according to Schultz (1993) and Demers and Joos (2007). However, competent brokers and industry-specialist auditors can also play a major role in helping start-ups, particularly small and emerging firms, to acquire resources for successful development. These expert intermediaries seem to influence the survival of newly listed firms significantly (Chou et al. 2006). The influence of VCs, auditors and investment bankers on the fate of newly listed companies inspires proposition 5:

\section{Proposition 5:}

a: The propensity of newly listed companies to fail (succeed) is significantly lower (higher) for VC-backed IPOs than for non-VC-backed IPOs.

b: The propensity of newly listed companies to fail (succeed) is significantly lower (higher) when the firm is audited by a prestigious auditor.

c: The propensity of newly listed companies to fail (succeed) is significantly lower (higher) when a prestigious investment banker is involved in the IPO.

\subsection{3) Control variable}

Young and less mature firms generally exhibit higher failure rates after entering the stock market (Weber and Willenborg 2003; Demers and Joos 2007). This can be traced to their lack of organizational structure and of human or financial resources. Smaller firms can also find it more difficult to face the costly requirements of a stock market. They also lack the necessary resources to survive when a market downturn reduces their capacity to get external equity. The negative relation between size at IPO and the failure risk is affirmed by Hensler et al. (1997) and Chou et al. (2006). Accordingly, we expect a negative relation between the size of the IPO and the delisting rate. The 20-year period we analyze is characterized by several sector-specific events: 
the bubble and crash in the high technologies sector, the robust increase in resources prices in the beginning of the 2000s, and the solid performance of the Energy sector beginning approximately in 2001. These events are likely to influence new listings, mortality and success rates of companies in each of these sectors. We cannot anticipate the sign of the association between the propensity to fail or succeed and the industry, but we expect to observe some influence, which can be time dependent. Several IPOs occur during Hot issue market periods, characterized by an excess demand for new issues, which attract lower quality issuers (Loughran and Ritter 2004). Accordingly, we expect a higher failure rate and a lower success rate for issues occurring during Hot issue market periods. We summarize the expected relation in the following propositions:

Proposition 6: The propensity of newly listed companies to fail (succeed) is significantly lower (higher) for mature firms than for younger firms.

Proposition 7: The propensity of newly listed companies to fail (succeed) is significantly lower (higher) for larger firms than for smaller firms.

Proposition 8: The propensity of newly listed companies to fail (succeed) is significantly linked to their industrial sector.

Proposition 9: The propensity of newly listed companies to fail (succeed) is significantly lower (higher) for firms that do not list in Hot issue markets than for firms that list in Hot issue markets.

\section{3) DATA AND CHARACTERISTICS OF THE SAMPLE}

\section{1) DATA SOURCES AND VARIABLE MEASUREMENT}

We collected the lists of IPOs from FPInfomart.ca since 1993 and from the annual lists of the Financial Post for the previous years. We excluded privatization of state-owned companies, demutualizations, creation of income trusts and Capital Pool Companies Program IPOs ${ }^{7}$. We obtained prospectuses from SEDAR (the Canadian equivalent of EDGAR) since 1997, and those of previous years from the Autorité des Marchés financiers du Québec, investment bankers and academic libraries. We supplemented the accounting information by using old versions of Thomson's CanCorp Financials. In Canada, because there is no equivalent to the CRSP delisting codes, we hand checked the status of the 2,373 issues at June 30, 2007 (and five and ten years

\footnotetext{
${ }^{7}$ The Capital Pool Program has been implemented in Canada to ease the creation of shells, ultimately used in reverse merger listings by operating companies (Carpentier and Suret 2006). Their IPOs result in the listing of a non-operating company; we consequently exclude CPC IPOs from our sample.
} 
after the issue). We first use the TSX and TSXV website to verify whether the issuer is still listed. For each of the delisted stocks, we identify the date, reason for and circumstances of delisting. TSXV provided a list of graduated companies from 1995 to mid-2007, and we supplement these data for the previous period using the monthly reviews of the exchanges. We collected the new cross-listings in the U.S. from the monthly reviews of TSX.

VBIPO is equal to 1 if a VC was involved in the company before the IPO. We obtained a partial list of VC-backed IPOs from Thomson Financial VC Reporter, a major provider of data on the VC industry. VC Reporter summarizes the deals made by the members of this industry in Canada. We supplemented and verified these data by analyzing the list of large shareholders in prospectuses. ${ }^{8}$ We thus identified 145 VC-backed IPOs. Following Carter and Manaster (1990), we consider the most active investment bankers in Canada prestigious. During the period under study, seven investment bankers subscribed to $60 \%$ of all the initial and seasoned equity issues, and are thus considered prestigious. ${ }^{9}$ We also consider as prestigious U.S. firms with a score higher than 7 in Carter et al. (1998). We add to this group international investment bankers such as BNP Paribas, Deutsche Bank and UBS, based on the list of the most active investment bankers worldwide provided by Ljungqvist et al. (2003 Table 2, p. 73). The dummy variable PUND is 1 when the investment banker is considered prestigious. PAUDIT $=1$ indicates prestigious auditors (“Big 5” or “Big 4”). Based on SIC codes, we defined three dummy variables, associated with High Tech, Energy and Materials (DHT, DEN and DMAT) respectively. AGE is the number of years since the incorporation of the issuer. We define AGE1=1 when AGE $<=5$ years and AGE2=1 when AGE $>5$ years. LOGSIZE is the natural logarithm of the post-issue shareholders' equity. We characterize Hot and Cold issue market periods following Helwege and Liang (2004), by estimating the three-month centered moving average of the IPO number. DHOT (DCOLD) has a value of 1 if the corresponding month is in the upper (lower) third of the moving average distribution.

\footnotetext{
${ }^{8}$ We compile a list of VCs operating in Canada from 1986 to 2003 from the lists of the Canadian VC Association, the summary of VC lists of Industry Canada (Strategis) and the lists of the equity sources provided by Mike Volker at http://www.sfu.ca/ mvolker/biz/moneylnk.htm.

${ }_{9}^{9}$ They are: RBC Capital Markets, CIBC World Market Inc., BMO Nesbitt Burns Inc., TD Securities Inc., Scotia Capital Inc., Merrill Lynch Canada Inc. and Goldman, Sachs \& Co. No other Canadian-based investment bankers control more than $5 \%$ of the total market.
} 


\section{2) ISSUER STATUS DETERMINATION}

\subsection{1) Non-surviving}

We consider as non-surviving all companies whose stocks were delisted by the exchange or subject to an issuer cease trade order at the time of the analysis, along with failed companies that are not yet delisted, those whose stocks are traded only over the counter or $\mathrm{NEX}^{10}$ and any stock which is used as a shell for a reverse takeover. In addition, we take into account the weakness of penny stock rules in Canada. Generally, stock exchanges delist companies whose stocks do not satisfy the ongoing listing requirements based on price, capitalization or volume. In Canada, before the NEX was created, in 2003, companies that fell below TSXV's ongoing listing requirements ${ }^{11}$ were designated inactive and given 18 months to meet the requirements or be delisted. To align our delisting definition with previous studies, we apply a rule which mimics the NASDAQ delisting practice as well as the decision criteria used by authors like Demers and Joos (2007). To complement the classical failure situations defined above, we consider as "dead" any stock which maintains a price lower than CAN\$0.1 for seven consecutive months. ${ }^{12}$ This rule applies to 233 of the 2,373 issues. However, in 49 of these cases, the application of the rule has the sole effect of producing a delisting date that is earlier than the one reported by the exchanges.

\subsection{2) Mergers and acquisitions}

Several acquisitions appear to be profitable for the investors, but others are clear failures, mainly after the burst of the technology bubble. We analyzed each of the 170 mergers and 467 acquisitions. In the case of mergers, we assume that the resulting company is a continuation of the issuer. In the case of acquisitions, we qualified as failures the 22 cases where the acquisition price is lower than CAN\$0.10.

\footnotetext{
${ }^{10}$ NEX is a new and separate board of TSXV that provides a trading forum for listed companies that have fallen below TSXV's ongoing listing requirements.

${ }^{11}$ The ongoing listing requirements describe the conditions of price, volume and financial characteristics that any listed firm must meet in order to avoid being delisted. NASDAQ delists a company if the stock trades under US\$1 for 30 days, and if the situation is not corrected during the following 6 months. In 2007, the ongoing listing requirements to Tier 2 of TSXV refer to a minimum market capitalization of CAN\$100,000, and minimum working capital of CAN\$50,000. No conditions apply to the stock price.

${ }^{12}$ We use the 10-cent limit given that Canadian IPO prices are, on average, one tenth of prices in the U.S.
} 


\subsection{3) Success}

As discussed by Audretsch and Lehmann (2005), developing a measure of success for small newly listed firms is challenging. Post-IPO growth rates of earnings or revenues are meaningless when the initial values are zero. Market-adjusted returns for thinly traded and highly volatile stocks are also questionable indicators of success. The reach of profitability can be a criterion only if none of the newly listed companies reports positive earnings at the IPO time.

For firms listed on TSXV, graduation to TSX equals success: as an incubator for emerging growth companies, TSXV encourages its "best customers to move to the senior market to access greater pools of liquidity.” During the period under analysis, 827 TSXV companies listed on TSX or, in a few cases, on a foreign market. A considerable body of research on exchange listings has identified three main reasons that motivate many firms to list their stocks abroad: the potential for reduced marketability costs; improvement in visibility and investor base; and the signaling of favorable future performance. We consider that each of the 1,849 TSXV IPO firms in our sample succeeds when it "graduates" to the main exchange. Our indicator relies on the assessment, by a senior exchange, that a firm is suitable for listing on this more senior market.

Our sample also includes 524 firms that list directly on the senior market, i.e. TSX, for which we need an indicator of success in line with the one used for the TSXV listing. We use the crosslisting toward a U.S. exchange. From 1986 to 2006, more than 510 Canadian companies crosslisted in the U.S. Companies list abroad to enjoy better visibility, improve their stock liquidity, reduce their cost of capital and benefit from a certification effect. They also list to access a larger pool of investors and to finance their expansion.

To ensure that graduation or cross-listing can indeed be considered success, we estimate the abnormal return for the sample of graduated and cross-listed Canadian firms during the three years preceding and following the listing on the new exchange, using the Fama-French factor model (1993). During the three years preceding the graduation, the monthly abnormal return for TSXV firms that graduate to TSX is a large $2.41 \%$ and is highly significant. For the three years before the graduation, the total abnormal return is $89.32 \%$. The corresponding values for TSX companies that cross-list are $0.89 \%$ and $33.27 \%$ respectively. Post-listing abnormal returns are 
negative but non-significant for graduate firms and near 0 for newly cross-listed firms. Accordingly, graduation and cross-listing can indeed be considered an indicator of success. ${ }^{13}$

\section{3) ChARACTERISTICS OF THE SAMPLE}

Table 1 presents the main characteristics of the 2,373 Canadian IPOs analyzed from 1986 to 2003, by sub-periods. The total gross proceeds are CAN $\$ 28.8$ billion. For the whole period, the median gross proceeds are CAN\$0.80 million. This low level is partly due to the 1986-1990 subperiod. The median gross proceeds are higher than CAN\$2 million from 1991 to 2000, and decrease to CAN\$1.68 million thereafter. The $90^{\text {th }}$ percentile of the gross proceeds distribution (CAN\$25.9 million) is roughly equivalent to US\$18 million. The median issue price ranges from CAN\$0.55 to CAN\$1.25 depending on the sub-period and is CAN\$0.75 overall. The $75^{\text {th }}$ percentile of the price distribution is equivalent to US\$2, and less than $5 \%$ of the issues are priced higher than US\$10. Even when compared with penny stocks or microcap issues in the U.S., Canadian IPOs appear to be very small, both in terms of issue prices and gross proceeds. Bradley et al. (2006) report mean gross proceeds of US\$5.7 million for penny stock IPOs, with an average offer price of US\$4.42. However, the most striking result is seen in shareholders' equity, estimated before the IPO. Overall, the median is CAN\$310,000 (Table 2). This size situates a large part of our sample in the area of very small businesses and clearly distinguishes our sample from those of the other studies of IPOs on new markets.

For each period, we report the proportions of issues in the main sectors. Natural resources companies represent $44.33 \%$ of new issues in Canada, reflecting the relative prominence of this activity in that country. High Tech firms account for $20.71 \%$ of new issuers, but the proportions of these two groups of issuers fluctuate considerably. We also report the proportion of issuers without sales and with negative earnings. For the whole period, the proportion of issuers with no sales is $45.32 \%$. From 1986 to 1990 , this proportion reaches $57.86 \%$. The new listing of firms at a development stage is therefore not a recent phenomenon in Canada. Overall, the proportion of

\footnotetext{
${ }^{13}$ Graduation and cross-listing are not perfect measures of success for IPOs, because some firms that fulfill the listing requirements of the major exchanges do not move their listing. We consider these firms to have survived, but not to have truly succeeded because they do not attempt to reach a more liquid market to finance their growth at a lower cost of capital. Our indicator is compatible with the proposition that the success of a new market can be assessed by its capacity to enable newly listed firms to raise the capital they need, developed by Bottazzi and Da Rin (2002).
} 
issuers reporting losses at IPO is slightly over $71 \%$, but reaches $77.65 \%$ and $78.79 \%$ during the first and the last sub-periods respectively.

\section{Insert Table 1 about here}

In Table 2, Panel A we present the distribution of the status of the issuers at June 30, 2007 and after 5 and 10 years. Overall, non-surviving issuers represent $48.52 \%$ of the sample. The global success rate (graduation or cross-listing) is $13.81 \%$ for the whole period. A proportion of $37.67 \%$ of issuers remain listed, but do not graduate to a higher level exchange. Therefore, in the long run, approximately 5 out of 10 new issuers in Canada fail, 1 succeeds and 4 stay alive but do not progress. We present a similar distribution when the issuer status is estimated 5 years after the IPO, to compare our results with those of previous studies. The proportion of non-surviving firms then falls to $11.60 \%$. This rate is in line with two results obtained in the U.S. for large IPOs (Schultz 1993; Bhabra and Pettway 2003), but is much lower than the delisting rate reported by all other published studies except for the 9.2\% estimated by Demers and Joos (2007) for High Tech companies. After 10 years, the delisting rate is $28.29 \%$. This is clearly less than the failure rate reported by the two studies that provide ten-year survival rates. Fama and French (2004) report a rate of $40.5 \%$ for the issuers whose size is below the median of the NYSE, and Hensler et al. (1997) estimate a rate of 55.1\%. Even for the group of firms without revenues at the IPO (NORM1), the delisting rate after 10 years is lower than the one observed in the U.S. (32.29\%).

Three U.S. studies deal specifically with penny stocks, comparable to, albeit larger than, Canadian IPOs. Weber and Willenborg (2003) report a delisting rate of $25.3 \%$ after 4 years, Bradley et al. (2006) a rate of 31.5\% after 3 years, and Dalbor and Sullivan (2005) estimate the failure rate at $44 \%$. Despite the fact that listing requirements are significantly more permissive than in the U.S. and even that a large proportion of new issuers report no sales, the survival rate of new issuers in Canada after 5 or 10 years is higher than that observed in the U.S.

This interesting result deserves an explanation. First, in the next section we examine the possible influence of the natural resources sector in greater detail. A large proportion of issuers originate from this sector, which presents strong performance during the last part of our period of analysis. Other explanations could be grounded in regulators' decision to apply lenient delisting rules, giving distressed firms more time to solve their problems, and easing the issuance of private placements. Our analysis (not reported) of these placements in Canada indicates that, from 1993 
to 2003 , $65.64 \%$ of private placements and $48.43 \%$ of seasoned equity offerings had been launched by non-profitable firms. The high survival rate can be partially explained by the capacity of public firms to issue private or public equity, even with negative earnings or no revenues. This result is important, because it suggests that the institutional setting can have a stronger impact on the survival of newly listed firms than the initial listing requirements.

Panel B of Table 2 presents the median of the main characteristics of the sample, according to the issuer status at the end of the period of analysis. ${ }^{14}$ The median issue price is CAN\$0.85 overall, but it is only CAN\$0.55 for non-surviving firms. This result is in line with the relation between post-listing performance and issue prices observed in the U.S. Median age at IPO varies according to the fate of the issuers. Non-survivors are two years old at the IPO, and surviving firms are four years old, illustrating the role of maturity in the survival of new issues. The nonsurviving firms are smaller: their median shareholders’ equity is CAN\$0.17 million.

\section{Insert Table 2 approximately here}

Table 3 presents the survival rates, in 2007, according to the main independent variables. The financial situation, and more generally the issuer situation relative to theoretical listing requirements, strongly influence survival rates. 61.37\% of NORM1 issuers (no revenues) delist, and $38.63 \%$ survive. The corresponding values are $12.50 \%$ and $87.50 \%$ for NORM4, with revenues, positive earnings and shareholders' equity over CAN\$25 million. The probability of success is approximately the same for the three groups that exhibit revenues at IPO. This rate ranges from $15.93 \%$ to $16.96 \%$. It is only $10.77 \%$ for issuers without revenues. A newly listed Canadian company at a pre-revenue stage thus succeeds in one case in 10 , and fails in approximately 6 cases out of 10 .

We observe strong variations between the success and failure rates depending on the sector. 63.22\% of Energy issuers survive. Several such issuers are acquired or merged, consistent with the intense consolidation in this sector, but only a few companies can be considered fire sales. The rate of graduation in this sector is $18.39 \%$, a result in line with the progression of oil prices toward the end of this period. The success rate of High Tech issuers is $21.90 \%$. As expected, prestigious intermediaries involved in the IPO process decrease the failure rate and increase the

\footnotetext{
${ }^{14}$ These medians can differ slightly from those reported in Table 3, because we are restricted by the availability of accounting data. We were able to collect this information for 2,028 of the 2,373 firms in the population (85.3\%).
} 
success rate. The effect is striking for VC: the failure rate for VC-backed issuers is less than $50 \%$ of that of non-VC-backed issuers (22.07\% vs. 50.56\%), and the success rate more than doubles when VC are involved (28.97\% vs. $12.64 \%)$. The issue period is linked to the probability of failure. This probability is higher when the issue happened during a Hot issue period (54.45\%), which is consistent with lower investor rationality during Hot issue periods. Issuers' maturity seems to play a role: nearly $57 \%$ of the youngest issuers (less than 5 years old) are delisted, versus $32.50 \%$ of the oldest issuers.

Insert Table 3 about here

\section{4) EMPIRICAL MODELS}

\section{1) METHOD}

Survival analysis is capable of processing censored data that represent situations where the response of interest (failure or success in our case) has not yet occurred. Therefore, the duration until the event is known for only a portion of the sample. In the presence of this censored distribution, conventional econometric OLS procedures are ill-suited to duration analysis, because they produce biased and inconsistent estimates.

We proceed in two stages. First, we use the Kaplan-Meier estimator (KME) to estimate the survival function and assess the individual effects of the main variables. The KME is defined as:

$$
\hat{S}(t)=\prod_{t_{i}<t} \frac{n_{i}-d_{i}}{n_{i}}
$$

where $n_{i}$ is the number of firms that are still at risk at time $t_{i}$ and $d_{i}$ is the number of firms that actually failed at time $t_{i}$. The KME provides a reading on the likelihood of survival at time $t$ based on the survival history of all firms. For each dependant variable, we segment the sample into two or more groups and calculate the KME for each group. We then use the Mantel-Haenszel log rank test to compare the differences between the groups. For each sub-group, we also estimate the median survival time.

In the second step, we select the widely used proportional hazards (PH) regression developed by Cox (1972) to model time-to-failure and time-to-success for IPO firms

$$
h(t \mid X)=h_{0}(t) \exp \left(X^{\prime} \beta\right)
$$


where $h(t)$ is the base-line hazard, $t$ is duration to date of failure or success, $X$ is a vector of independent variables and $\beta$ is a vector of parameters to be estimated. The inference of $\beta$ is based on a partial likelihood approach. The parameters can be estimated without specifying the baseline hazard function. The main advantage of a Cox PH model is that we are not required to make any assumptions about the underlying distribution of the data.

\section{2) RESULTS}

\subsection{1) Survival functions}

In the first step, we estimate the KME for the whole sample, focusing on survival vs. nonsurvival dichotomy. The KME yields a preliminary estimate of the mean (median) survival time of newly listed firms in Canada of 13.81 (15.08) years.

Panel A of Table 4 shows that the delisting probability is significantly lower (37.87\%) for an issuer with revenues at IPO than for issuers without revenues (61.37\%), and the mean delisting time increases from 12.88 years to 14.62 years when firms exhibit revenues at IPO. Issuers with positive earnings have a lower delisting rate (28.06\%) than issuers with negative earnings (56.88\%). The mean delisting time increases from 12.94 years to 15.99 years when companies report positive earnings at IPO. This result is consistent with the previous U.S. results linking the profitability of issuers to their survival and success. Moreover, the delisting probability is $12.5 \%$ for the largest profitable issuers. The p values indicate that the differences between the groups are highly significant. We also analyze the survival functions for the time to success (Table 4, Panel B). The proportion of success is $16.32 \%$ (10.77\%) for issuers with (without) revenues, and the mean time to success is 16.30 and 18.79 years respectively. The difference is significant, but smaller than one would expect. This is probably due to the large proportion of issuers with no revenues in the natural resources sectors, whose expansion enabled several companies to graduate. A similar pattern was observed for profitability. The proportions of success range from $15 \%$ to $17 \%$ in the groups based on the level of minimum listing requirements (NORM variables), except for NORM1 (no revenues, 10.77\%).

Insert Table 4 about here.

This analysis of the survival functions evidences issuers' differences, which are mainly linked to their financial situation at IPO and, accordingly, the level of initial listing requirements they meet. Globally, these results are in line with our propositions 1 to 4 . The survival probability is 
significantly lower when the issuer has no revenues or has negative earnings. However, as several variables are linked, only the simultaneous analysis of these variables can yield robust conclusions.

\subsection{2) Semi-parametric models: time to failure}

The results of the estimated Cox PH models are reported in Table 5 for the survival analysis. The dependent variable is the logarithm of the hazard rate. As the dependent variable is based on the delisting occurrence, a positive (negative) coefficient indicates that an increase in the variable leads to an increase (decrease) in the probability of delisting. We also report the risk ratios. For a dichotomous variable, this is the ratio of the hazard for "1" to the hazard for "0, " while controlling for all other covariates. A risk ratio of 0.784 (for variable AGE2), for example, indicates that the failure risk of an issuer aged 5 years or more is $78.4 \%$ of the failure risk of a younger firm, when controlling for other covariates. We estimate four forms of the model. In model 1 , we use all variables except those associated with the intermediaries. We introduce these variables in model 2, to assess their marginal contribution, because they are likely to be correlated with the NORM variables. In model 3 we split the sample according to profitability. In model 4, we isolate the issuers without revenues (NORM1).

Insert Table 5 about here

The overall model Chi-square statistic indicates that all forms of the model are highly significant. The estimated coefficients and their levels of significance are stable across the various specifications, and we focus our detailed analysis on Model 2. All variables are significant except the variables associated with the High Tech industry and the Hot issue market period. This overall result indicates that the survival of new issuers is significantly associated with the characteristics prevailing at the IPO and with the level of initial listing requirements they meet.

Financial conditions prevailing before the IPO, summarized in the NORM indicator, strongly influence the risk ratio. The coefficients of the dummy variables NORM1 (no revenues) and NORM2 (revenues and negative earnings) are largely significant. The positive coefficient indicates that issuers of these groups have a shorter life expectancy than the other issuers. If we group all non-profitable issuers (regardless of whether these issuers have revenues or not) the coefficient is still highly significant. The risk ratio indicates that the failure risk of non-profitable issuers is 1.77 times the failure risk of profitable issuers (model 3). The Chi square decreases to 
199.70, which indicates that it is important to separate non-profitable issuers according to their revenue dimension to better capture the survival probability. This risk ratio is a direct measure of the additional delisting risks that arise when the exchange and the regulator skip the profitability requirement for new listings. In model 4, we observe that the parameter associated with the norevenue dummy variable is also positive and significant. The delisting risk of new issuers with no revenues is 1.23 times greater than the corresponding values for the other issuers, including those with revenues but negative earnings. ${ }^{15}$ This illustrates the significant role of minimum listing requirements on the survival of new issuers, and affirms the part of our propositions 1 to 4 that is related to the propensity to fail.

The AGE2 (more than five years) variable is also negative and significant: older issuers have a lower failure risk than younger ones, in line with the failure part of our proposition 6 . The hazard risk ratio indicates that older issuers represent a failure risk of $78.4 \%$ relative to the younger ones. The coefficient of the LOGSIZE variable is negative and highly significant whatever the model: larger issuers have a lower failure risk. This is in line with the failure dimension of proposition 7. In model 2, we add the PUND and PAUDIT variables, which are proxies for the prestige of the underwriter and the auditor. The Chi square increases to 217 from 204, which implies that underwriters and auditors are linked to the failure probability, beyond the other characteristics of the issuers. Hiring prestigious underwriters and auditors significantly decreases the failure risk, all other things being equal. This result can be attributable to the consulting and monitoring functions of these practitioners or to their screening abilities. The hazard ratios of 0.847 and 0.807 for auditors and investment bankers indicates that the reduction in failure risk associated with the involvement of prestigious intermediaries is important. The VBIPO variable is significant at the $10 \%$ level only in model 3 . When all variables are accounted for, VC involvement explains the failure rate of new issuers only marginally. These results confirm part of our proposition $5 \mathrm{~b}$ and $5 \mathrm{c}$ related to the propensity to fail.

We do not observe any significant influence of the variable related to the High Tech sector. However, the coefficients of the sector dummy related to the Material and Energy sectors (DMAT and DEN) are negative and significant. The firms belonging to these sectors present a

\footnotetext{
${ }^{15}$ We also test a model with a separation between NORM4 and the other groups, omitting the size variable (not reported). The coefficient associated with NORM4 is negative and highly significant. Issuers that approximate the recent NASDAQ minimum listing requirements exhibit a failure risk of $27.8 \%$ of the risk of the other issuers.
} 
lower probability of failure than those belonging to technologies or other sectors. The risk ratio indicates that firms in these sectors present a failure risk of $71.8 \%$ (Materials) and 57.8\% (Energy) of the risk of firms belonging to other sectors. This result can probably be traced to the high prices of natural resources during the last part of our period of analysis. Our proposition 8 is thus partially supported, for the failure dimension.

\subsection{3) Semi-parametric models: time to success}

In Table 6, we report the coefficient of the models that explain the time elapsed until success. A positive coefficient in an explanatory variable model indicates that an increase in the variable is associated with an increase in the hazard and lower duration until graduation. The models are globally significant, but very few variables appear to receive a significant coefficient. Generally, the time to success is not significantly related to the NORM variables (models 1 to 4 ). The presence of revenues or positive earnings at IPO is not associated with the probability of graduation to a higher level market. This situation can be seen as a paradox. Our explanation is that the success of a large proportion of our sample is associated with a discovery in the case of resources companies, or with a successful $R \& D$ program in the case of high technologies companies. Collectively, these two groups constitute approximately two thirds of our sample.

The coefficient of the LOGSIZE variable is highly significant and positive for all models. Larger IPO issuers have a higher success rate than smaller ones. This result makes sense, because access to a higher level market is generally based on size-related requirements. The sectors also influence the probability of success. The probability of success in Energy (Materials) is 2.6 (1.8) times the same probability of another sector, which can be traced to the rising prices of natural resources during the last part of our period of analysis.

The probability of success is significantly higher for IPOs when a prestigious auditor is hired: the risk ratio is 1.8. Surprisingly, the opposite effect appears with the dummy variables associated with investment banker prestige. Here, the coefficient is negative and significant. We do not have a satisfactory explanation for this unexpected result. ${ }^{16}$ The VBIPO variable is highly significant. The risk ratio indicates that, all other things being equal, a VC-backed issuer is 1.8 times more likely to graduate (succeed) than a non-VC-backed issuer. This result is consistent with previous

${ }^{16}$ One possible explanation we analyzed is a multicollinearity problem, although the correlation coefficients between PSOUS and most variables are rather low. However, we use a stepwise method to assess the effect of this collinearity on the results. The model and coefficients estimated using this approach are similar to those reported in Table 6. 
studies indicating that VC-backed IPOs exhibit, on average, better long-run performance than non-VC-backed IPOs. The IPO context thus influences the probability of success. The coefficient of the DHOT variable is negative and highly significant, which indicates that Hot issues are less likely to succeed, a result consistent with the previous evidence. The risk ratio indicates that the probability of graduation of an IPO introduced during a Hot issue market is $75 \%$ of the

probability of such an outcome for an IPO launched during Cold and neutral periods. Overall, few variables specific to the issuers can help to predict the success of an IPO. The certification effect of auditors and VC appears to be the only significant predictor of success, and this success depends on the general condition of the IPO market.

Insert Table 6 about here

\subsection{4) Sector effects}

In our sample, $58.76 \%$ of NORM1 issuers belong to the Materials sector. To assess the effects of this situation on our results, we report the results of Cox PH models 2 and 4 in Table 7, for all observations excluding Materials companies, and for Materials issuers only. Excluding Materials does not change the coefficients or their significance levels for the explanation of the time to failure. In the Materials sector, the choice of prestigious intermediaries has no influence on the time to failure. The explanatory power is much lower than in the other sectors (17.24 vs. 203.29), reflecting the unpredictable nature of Materials company failure. Similar observations can be made regarding the models that explain the success probability. Exclusion of Materials does not change the estimated parameter or the significance levels, except the coefficients of the variables associated with the intermediaries' prestige, for which the significance levels decrease considerably. As in the case of time to failure, the probability of success in the Materials sector is unpredictable. This part of the analysis indicates that our results are not driven by the particular characteristics of the Materials sub-sector.

Hot market periods can differ between the main sectors. We study a possible interaction effect between sectors and hot issue periods as follows. First, we introduce interaction variables in the various models. These variables are given by the product of the DHOT variable with the various dummies associated with the sectors. None of the interaction variables appears significant, and we do not report these results. Second, we run the models according to the situation of the market (Hot or not Hot). We do not observe material changes in the coefficients and significance levels 
compared with those reported in Table 7. Our sample does not provide significant evidence of an interaction effect between the IPO activity and the industry of IPO firms. A possible explanation for this result is that there are too few periods of time where significant differences appear between the new issue activities of the various industries.

Insert Table 7 about here

\subsection{5) Summary of results}

Table 8 summarizes the results that confirm our initial propositions. Essentially, the level of listing requirements newly listed firms meet significantly influences their propensity to fail, but has no impact on the propensity to succeed. Venture-backed IPOs are more likely to succeed, but the involvement of VC has no effect on failure risk. Reputational auditors and investment bankers decrease the probability of failure, yet prestigious investment bankers are associated with a significantly lower rate of success, an unexpected result. Other control variables have the expected influence.

Insert Table 8 about here

\section{CONCLUSION}

Allowing firms to enter the stock market at a pre-revenue stage is a perilous strategy. Only a small proportion of those issuers survive, and few reach a higher level stock exchange. However, the Canadian IPOs' failure rate is lower than that of their counterparts in the U.S. Two elements likely explain this situation. First, a Canadian company can easily issue private or public equity before reaching the profitability or even the revenue stage. The second explanation is the tolerance of the exchange in terms of delisting of non-operating companies. These two elements make it possible for numerous firms to survive in the market without earnings and to finance their R\&D or exploration expenses. Canada seems to have developed a particular strategy to finance growing firms, and allowing penny stock IPOs should not be ruled out if practices in the secondary markets are adjusted, and perhaps if prestigious intermediaries are involved.

Our second finding is that the initial listing requirements have a significant effect on the survival of the IPO issuer. The survival probability is significantly lower when the issuer has no revenues or has negative earnings. The survival of new issuers is significantly associated with the characteristics prevailing at the IPO (size, age and sector) and with the level of initial listing 
requirements they meet. The effects of the listing requirements seem to be mitigated significantly by the involvement of prestigious auditors and investment bankers.

The success probability of the issuer is not linked to the financial conditions at IPO. The time to success has a weak relation with the characteristics of the issuers at the IPO. Size, industry and market conditions are the only significant variables to explain this success probability. Nonetheless, if the involvement of a venture capitalist has only a marginal effect on the probability of failure, it influences the probability of success significantly.

Our analysis can be extended to other countries, mainly in Europe where several junior markets have been ravaged by the current crisis, and on several dimensions. We link the low delisting rate to the lax delisting rules applied in Canada, where distressed firms can remain listed until their situation improves. Its takes often a long time for a small firm to reach the profitability threshold, and strict delisting rules may be ill suited to markets devoted to the listing of small businesses. The fate of firms delisted from the junior markets due to strict delisting rules can be an insightful topic for future research. Our analysis does not consider several dimensions linked to management skills and previous work experience. These variables appear to influence the performance of new firms significantly. Adding such variables can provide the required information to guide regulators as they fine-tune initial and ongoing listing requirements. The involvement of high level auditors in very small and risky operations deserves analysis, together with the explanation of their apparent capacity to partially discriminate between good and bad prospects. We also have left for further research the effects of low listing requirements on the investors' rate of return. A recent paper by Locke and Gupta (2008) indicates that, on the New Zealand markets, small firms listed on the junior market perform worse than those listed on the main board, contrary to the expectation based on the small firm effect and the risk-return tradeoff. The detailed analysis of the returns of Canadian small public firms can provide complementary evidence on this anomaly. 
TABLE 1 Main characteristics of Canadian initial public offerings (IPOs), by sub-period, 1986-2003

\begin{tabular}{cccccccccc}
\hline Period & $\#$ & $\begin{array}{c}\text { Total GP } \\
\text { in \$M }\end{array}$ & $\begin{array}{c}\text { Mean GP } \\
\text { in \$M }\end{array}$ & $\begin{array}{c}\text { Median GP } \\
\text { in \$M }\end{array}$ & $\begin{array}{c}\text { Median } \\
\text { Issue Price }\end{array}$ & \% HT & \% NR & \% REV0 & \% EPSN \\
\hline $1986-1990$ & 1257 & $6,272.41$ & 4.99 & 0.36 & 0.55 & 12.88 & 48.48 & 57.86 & 77.65 \\
$1991-1995$ & 441 & $8,887.98$ & 20.15 & 2.50 & 1.25 & 25.48 & 38.78 & 26.87 & 54.29 \\
$1996-2000$ & 575 & $12,088.89$ & 21.02 & 2.05 & 1.00 & 33.59 & 36.33 & 31.84 & 67.58 \\
$2001-2003$ & 100 & $1,550.54$ & 15.51 & 1.68 & 0.55 & 20.20 & 61.62 & 48.48 & 78.79 \\
\hline $1986-2003$ & 2,373 & $28,799.83$ & 12.14 & 0.80 & 0.75 & 20.71 & 44.33 & 45.32 & 71.01 \\
\hline
\end{tabular}

The sample consists of 2,373 firms that make IPOs during the 1986-2003 period. These issues consist of common shares and other categories of securities (units comprising shares, preferred shares and flow-through shares). Fixed income securities, trust units, limited partnership units and shares resulting from demutualization and privatization are excluded. Gross proceeds (GP) are in CAN\$ million (\$M). Variable definitions are as follows: \%HT is the percentage of High Tech issuers; \%NR is the percentage of Materials and Energy issuers, $\% \mathrm{REV0}$ is the percentage of issuers without revenues and \%EPSN is the percentage of issuers with negative earnings per share at the issue.

TABLE 2 Distribution of initial public offerings (IPOs) between 1986 and 2003, for which accounting data are available, by survival status.

\begin{tabular}{|c|c|c|c|c|c|c|c|c|c|c|}
\hline & \multicolumn{2}{|c|}{ Non-Surviving } & \multicolumn{2}{|c|}{$\begin{array}{c}\text { Surviving } \\
\text { unsuccessful }\end{array}$} & \multicolumn{2}{|c|}{$\begin{array}{l}\text { Surviving } \\
\text { successful }\end{array}$} & \multicolumn{2}{|c|}{$\begin{array}{c}\text { Total } \\
\text { surviving }\end{array}$} & \multicolumn{2}{|c|}{ Total } \\
\hline \multicolumn{11}{|c|}{ Panel A: Survival status of IPOs } \\
\hline & $\mathrm{Nb}$ & $\%$ & $\mathrm{Nb}$ & $\%$ & $\mathrm{Nb}$ & $\%$ & $\mathrm{Nb}$ & $\%$ & $\mathrm{Nb}$ & $\%$ \\
\hline Whole sample & 984 & 48.52 & 764 & 37.67 & 280 & 13.81 & 1,044 & 51.48 & 2,028 & 100.00 \\
\hline 5 years & 229 & 11.60 & 1,608 & 81.46 & 137 & 6.94 & 1745 & 88.40 & 1,974 & 100.00 \\
\hline 10 years & 454 & 28.29 & 1,063 & 66.23 & 88 & 5.48 & 1151 & 71.71 & 1,605 & 100.00 \\
\hline \multicolumn{11}{|c|}{ Panel B: Characteristics of issuers, according to their status in June 2007} \\
\hline & Mean & Median & Mean & Median & Mean & Median & Mean & Median & Mean & Median \\
\hline Issue Price, $\$$ & 1.52 & 0.55 & 4.55 & 1.63 & 4.36 & 1.25 & 4.50 & 1.50 & 3.06 & 0.85 \\
\hline GP, in $\$ M$ & 3.62 & 0.50 & 25.51 & 3.00 & 16.28 & 2.50 & 23.03 & 3.00 & 13.61 & 0.94 \\
\hline Age at IPO & 4.88 & 2.07 & 9.90 & 4.31 & 7.25 & 3.25 & 9.19 & 4.03 & 7.11 & 2.75 \\
\hline $\mathrm{SE}$, in $\$ \mathrm{M}$ & 10.55 & 0.17 & 21.48 & 0.98 & 14.31 & 0.69 & 19.56 & 0.88 & 15.19 & 0.31 \\
\hline
\end{tabular}

Panel A presents the survival status on June 30, 2007, five years after the issue and ten years after the issue. Panel B presents the main characteristics of the whole sample of IPOs, depending on their status in June 2007. Gross proceeds (GP) and shareholders' equity before the issue (SE) are expressed in millions of Canadian dollars (M\$). Issue price is expressed in Canadian dollars (\$). Age at IPO is expressed in years and issue price in Canadian dollars. Sources: Financial Post, FPinformart.ca, Corporate Retriever, SEDAR and Internet. 
TABLE 3 Descriptive statistics on independent variables.

\begin{tabular}{|c|c|c|c|c|c|}
\hline & $\begin{array}{c}\text { Non- } \\
\text { surviving } \\
\text { in } \% \\
\end{array}$ & $\begin{array}{c}\text { Surviving } \\
\text { unsuccessful } \\
\text { in \% }\end{array}$ & $\begin{array}{l}\text { Surviving } \\
\text { successful } \\
\text { in } \% \\
\end{array}$ & $\begin{array}{l}\text { Surviving } \\
\text { total } \\
\text { in } \% \\
\end{array}$ & $\begin{array}{l}\text { Total } \\
\text { in } \%\end{array}$ \\
\hline \multicolumn{6}{|l|}{ Profitability and norm } \\
\hline NORM1 (no rev) & 61.37 & 27.86 & 10.77 & 38.63 & 100.00 \\
\hline NORM2 (rev, EPS<0) & 48.94 & 34.74 & 16.31 & 51.06 & 100.00 \\
\hline NORM3 (EPS $>0$ and $S E<=25)$ & 37.64 & 46.43 & 15.93 & 62.36 & 100.00 \\
\hline NORM4 (EPS>0 and SE > 25) & 12.50 & 70.54 & 16.96 & 87.50 & 100.00 \\
\hline NORM12 $(\mathrm{EPS}<0)$ & 56.88 & 30.35 & 12.78 & 43.13 & 100.00 \\
\hline NORM34 (EPS>0) & 28.06 & 55.61 & 16.33 & 71.94 & 100.00 \\
\hline NORM234 (rev) & 37.87 & 45.81 & 16.32 & 62.13 & 100.00 \\
\hline \multicolumn{6}{|l|}{ Sector } \\
\hline High Tech & 44.29 & 33.81 & 21.90 & 55.71 & 100.00 \\
\hline Materials & 55.33 & 33.70 & 10.97 & 44.67 & 100.00 \\
\hline Energy & 36.78 & 44.83 & 18.39 & 63.22 & 100.00 \\
\hline Other & 49.22 & 40.90 & 9.87 & 50.78 & 100.00 \\
\hline \multicolumn{6}{|l|}{ Auditor } \\
\hline Prestigious & 38.27 & 41.15 & 20.58 & 61.73 & 100.00 \\
\hline Non-prestigious & 53.86 & 35.86 & 10.28 & 46.14 & 100.00 \\
\hline \multicolumn{6}{|l|}{ Underwriter } \\
\hline Prestigious & 30.16 & 55.82 & 14.02 & 69.84 & 100.00 \\
\hline Non-prestigious & 52.73 & 33.52 & 13.76 & 47.27 & 100.00 \\
\hline \multicolumn{6}{|l|}{ Venture capitalists } \\
\hline Non-VC-backed issuers & 50.56 & 36.80 & 12.64 & 49.44 & 100.00 \\
\hline VC-backed issuers & 22.07 & 48.97 & 28.97 & 77.93 & 100.00 \\
\hline \multicolumn{6}{|l|}{ Period } \\
\hline Hot & 54.45 & 33.42 & 12.13 & 45.55 & 100.00 \\
\hline Cold & 44.44 & 45.83 & 9.72 & 55.56 & 100.00 \\
\hline \multicolumn{6}{|l|}{ Age } \\
\hline AGE $1<=5$ years & 56.60 & 30.64 & 12.76 & 43.40 & 100.00 \\
\hline AGE2> 5 years & 32.50 & 51.62 & 15.88 & 67.50 & 100.00 \\
\hline
\end{tabular}

Descriptive statistics are provided by status on June 30, 2007 for 2,028 IPOs between 1986 and 2003 for which accounting data are available. SE means shareholders' equity and is expressed in millions of CAN\$. EPS means earnings per share. 
TABLE 4 Non-parametric analyses of the survival and time-to-success functions.

\begin{tabular}{|c|c|c|c|c|}
\hline Variables & $\begin{array}{l}\text { Number } \\
\text { of } \\
\text { issuers }\end{array}$ & $\begin{array}{c}\text { Mean } \\
\text { Time } \\
\text { (in years) }\end{array}$ & $\begin{array}{c}\text { Number of events } \\
\text { (percentage of } \\
\text { events) }\end{array}$ & $\begin{array}{c}\text { Test Log } \\
\text { Rank } \\
\text { (p value) }\end{array}$ \\
\hline \multicolumn{5}{|l|}{ Panel A: Time to failure } \\
\hline \multicolumn{5}{|l|}{ Revenues } \\
\hline NORM1 (no rev) & 919 & 12.88 & $564(61.37)$ & 55.0177 \\
\hline NORM234 (rev) & 1,109 & 14.62 & $420(37.87)$ & $(<0.0001)$ \\
\hline \multicolumn{5}{|l|}{ EPS } \\
\hline NORM12 (EPS $<=0)$ & 1,440 & 12.94 & $819(56.88)$ & 102.9800 \\
\hline NORM34 (EPS>0) & 588 & 15.99 & $165(28.06)$ & $(<0.0001)$ \\
\hline \multicolumn{5}{|l|}{ Norms } \\
\hline NORM1 (no rev.) & 919 & 12.88 & $564(61.37)$ & \multirow{4}{*}{$\begin{array}{l}120.2473 \\
(<0.0001)\end{array}$} \\
\hline NORM2 (rev and EPS <=0) & 521 & 12.47 & $255(48.94)$ & \\
\hline NORM3 (EPS $>0$ and $S E<=25)$ & 364 & 14.93 & $137(37.64)$ & \\
\hline NORM4 (EPS $>0$ and SE $>25$ ) & 224 & 15.96 & $28(12.50)$ & \\
\hline \multicolumn{5}{|l|}{ Panel B: Time to success } \\
\hline \multicolumn{5}{|l|}{ Revenues } \\
\hline NORM1 (no rev) & 919 & 18.79 & $99(10.77)$ & \multirow{3}{*}{$\begin{array}{c}17.8137 \\
(<0.0001)\end{array}$} \\
\hline NORM234 (rev) & 1,109 & 16.30 & $181(16.32)$ & \\
\hline \multicolumn{4}{|l|}{ EPS } & \\
\hline NORM12 (EPS $<=0)$ & 1,440 & 18.35 & $184(12.78)$ & \multirow{3}{*}{$\begin{array}{c}5.9273 \\
(0.0149)\end{array}$} \\
\hline NORM34 (EPS $>0)$ & 588 & 15.23 & $96(16.33)$ & \\
\hline \multicolumn{4}{|l|}{ Norms } & \\
\hline NORM1 (no rev) & 919 & 18.79 & $99(10.77)$ & \multirow{4}{*}{$\begin{array}{l}18.8314 \\
(0.0003)\end{array}$} \\
\hline NORM2 (rev and EPS<=0) & 521 & 16.35 & $85(16.31)$ & \\
\hline NORM3 (EPS $>0$ and $S E<=25)$ & 364 & 15.48 & $58(15.93)$ & \\
\hline NORM4 (EPS $>0$ and SE $>25)$ & 224 & 14.81 & $38(16.96)$ & \\
\hline
\end{tabular}

The sample comprises 2,028 issuers of IPOs for the 1986-2003 period. In Panel A, events are failures. In Panel B, events are successes. EPS means earnings per share. SE means shareholders' equity and is expressed in millions of CAN\$. Rev means revenues. 
TABLE 5 Coefficient estimates and p-values from multivariate Cox Hazard Models, time to failure. Hazard (risk) ratios appears between brackets

\begin{tabular}{|c|c|c|c|c|c|}
\hline Variables & $\begin{array}{l}\text { Expected } \\
\text { relation }\end{array}$ & IPO-Model 1 & IPO- Model 2 & IPO-Model 3 & IPO- Model 4 \\
\hline NORM1 & + & $\begin{array}{l}1.3673 * * * \\
(<0.0001)[3.925]\end{array}$ & $\begin{array}{l}1.2980 * * * \\
(<0.0001)[3.662]\end{array}$ & & $\begin{array}{l}0.2052 * * * \\
(0.0095) \text { [1.228] }\end{array}$ \\
\hline NORM2 & + & $\begin{array}{l}1.2827 * * * \\
(<0.0001)[3.606]\end{array}$ & $\begin{array}{l}1.2410 * * * \\
(<0.0001)[3.459]\end{array}$ & & \\
\hline NORM3 & - & $\begin{array}{l}0.9013 * * * \\
(<0.0001)[2.463]\end{array}$ & $\begin{array}{l}0.8312 * * * \\
(0.0001)[2.296]\end{array}$ & & \\
\hline NORM12 & + & & & $\begin{array}{l}0.5725^{* * *} \\
(<0.0001) \\
{[1.773]}\end{array}$ & \\
\hline PAUDIT & - & & $\begin{array}{l}-0.1661 * * \\
(0.0319)[0.847]\end{array}$ & $\begin{array}{l}-0.1439 * \\
(0.0615)[0.866]\end{array}$ & $\begin{array}{l}-0.1367 * \\
(0.0764) \text { [0.872] }\end{array}$ \\
\hline PUND & - & & $\begin{array}{l}-0.2149 * * \\
(0.0381)[0.807]\end{array}$ & $\begin{array}{l}-0.3015^{* * * *} \\
(0.0033)[0.740]\end{array}$ & $\begin{array}{l}-0.3002 * * * \\
(0.0034)[0.741]\end{array}$ \\
\hline VBIPO & - & & $\begin{array}{l}-0.2835 \\
(0.1316) \text { [0.753] }\end{array}$ & $\begin{array}{l}-0.3131^{*} \\
(0.0946)[0.731]\end{array}$ & $\begin{array}{l}-0.2827 \\
(0.1319)[0.754]\end{array}$ \\
\hline LOGSIZE & - & $\begin{array}{l}-0.0659 * * * \\
(0.0001)[0.936]\end{array}$ & $\begin{array}{l}-0.0489 * * * \\
(0.0078)[0.952]\end{array}$ & $\begin{array}{l}-0.0657 * * * \\
(0.0002)[0.936]\end{array}$ & $\begin{array}{l}-0.0965^{* * *} \\
(<0.0001) \\
{[0.908]}\end{array}$ \\
\hline AGE2 & - & $\begin{array}{l}-0.2563 * * * \\
(0.0020)[0.774]\end{array}$ & $\begin{array}{l}-0.2436 * * * \\
(0.0033)[0.784]\end{array}$ & $\begin{array}{l}-0.2654 * * * \\
(0.0014)[0.767]\end{array}$ & $\begin{array}{l}-0.3283^{* * *} \\
(<0.0001) \\
{[0.720]}\end{array}$ \\
\hline DMAT & & $\begin{array}{l}-0.3019 * * * \\
(0.0002)[0.739]\end{array}$ & $\begin{array}{l}-0.3307 * * * \\
(<0.0001)[0.718]\end{array}$ & $\begin{array}{l}-0.3119 * * * \\
(0.0001)[0.732]\end{array}$ & $\begin{array}{l}-0.2751 * * * \\
(0.0009)[0.760]\end{array}$ \\
\hline DEN & & $\begin{array}{l}-0.5073 * * * \\
(<0.0001)[0.602]\end{array}$ & $\begin{array}{l}-0.5482 * * * \\
(<0.0001)[0.578]\end{array}$ & $\begin{array}{l}-0.5289 * * * \\
(<0.0001) \\
{[0.589]}\end{array}$ & $\begin{array}{l}-0.4803^{* * *} \\
(<0.0001) \\
{[0.619]}\end{array}$ \\
\hline DHT & & $\begin{array}{l}-0.0165 \\
(0.8590) \text { [0.984] }\end{array}$ & $\begin{array}{l}0.0093 \\
(0.9208) \text { [1.009] }\end{array}$ & $\begin{array}{l}0.0146 \\
(0.8753) \text { [1.015] }\end{array}$ & $\begin{array}{l}0.0842 \\
(0.3635) \text { [1.088] }\end{array}$ \\
\hline DHOT & + & $\begin{array}{l}-0.0876 \\
(0.1910)[0.916]\end{array}$ & $\begin{array}{l}-0.0786 \\
(0.2410)[0.924]\end{array}$ & $\begin{array}{l}-0.0665 \\
(0.3213)[0.936]\end{array}$ & $\begin{array}{l}-0.0694 \\
(0.3000) \text { [0.933] }\end{array}$ \\
\hline Chi-Square & & $\begin{array}{l}203.5187^{* * *} \\
(<0.0001)\end{array}$ & $\begin{array}{l}216.7786^{* * *} \\
(<0.0001)\end{array}$ & $\begin{array}{l}199.6956 * * * \\
(<0.0001)\end{array}$ & $\begin{array}{l}174.9608^{* * * *} \\
(<0.0001)\end{array}$ \\
\hline Number & & 2,028 & 2,028 & 2,028 & 2,028 \\
\hline
\end{tabular}

Cox Proportional Hazard models are estimated using a sample of 2,028 IPOs over the 1986-2003 period. The time to failure is measured as the number of months elapsed between the IPO month and the month in which the firm is delisted from TSXV for negative reasons. The results for each model include the estimated coefficient of each independent variable, the associated p-values in parentheses ( ) and the risk ratio between brackets [ ]. NORM1 is a dummy variable equal to 1 if the issuer has no revenues, NORM2 is equal to 1 if the issuer has revenues and earnings per share (EPS) is negative, NORM3 is equal to 1 if the issuer has positive EPS and shareholders' equity is less than \$25 million, NORM12 is equal to 1 if the issuer has negative EPS. PAUDIT is an indicator variable equal to 1 if the firm hired a prestigious audit firm. PUND is an indicator variable equal to 1 if the firm hired a prestigious underwriter firm. LOGSIZE is defined by the natural logarithm of the post-IPO net assets. AGE2 is a dummy variable equal to 1 if the firm is more than five years old. DMAT is a dummy variable set to 1 if the industry of an issuer is Materials, DEN is a dummy variable set to 1 if the industry of an issuer is Energy and DHT is a dummy variable set to 1 if the issuer produces high-tech products based on the SIC identification and 0 otherwise. DHOT is a dummy variable set to 1 if the IPO occurs during a Hot issue market period and 0 otherwise. 
TABLE 6 Coefficient estimates from multivariate Cox Hazard Models, time to success

\begin{tabular}{|c|c|c|c|c|c|}
\hline Variables & $\begin{array}{l}\text { Expected } \\
\text { relation }\end{array}$ & IPO-Model 1 & IPO- Model 2 & IPO-Model 3 & IPO- Model 4 \\
\hline NORM1 & - & $\begin{array}{l}0.2555 \\
(0.3396) \text { [1.291] }\end{array}$ & $\begin{array}{l}0.0950 \\
(0.7240) \text { [1.100] }\end{array}$ & & $\begin{array}{l}-0.0683 \\
(0.6785)[0.934]\end{array}$ \\
\hline NORM2 & - & $\begin{array}{l}0.4191^{*} \\
(0.0705) \text { [1.521] }\end{array}$ & $\begin{array}{l}0.2200 \\
(0.3476)[1.246]\end{array}$ & & \\
\hline NORM3 & + & $\begin{array}{l}0.3062 \\
(0.1864)[1.358]\end{array}$ & $\begin{array}{l}0.0736 \\
(0.7563)[1.076]\end{array}$ & & \\
\hline NORM12 & - & & & $\begin{array}{l}0.1258 \\
(0.4161)[1.134]\end{array}$ & \\
\hline PAUDIT & + & & $\begin{array}{l}0.5979 * * * \\
(<0.0001)[1.818]\end{array}$ & $\begin{array}{l}0.6041^{* * *} \\
(<0.0001)[1.830]\end{array}$ & $\begin{array}{l}0.6093^{* * *} \\
(<0.0001) \\
{[1.839]}\end{array}$ \\
\hline PUND & + & & $\begin{array}{l}-0.4198 * * \\
(0.0188)[0.657]\end{array}$ & $\begin{array}{l}-0.4405^{* *} \\
(0.0116)[0.644]\end{array}$ & $\begin{array}{l}-0.4252 * * \\
(0.0149)[0.654]\end{array}$ \\
\hline VBIPO & + & & $\begin{array}{l}0.5804 * * * \\
(0.0020) \text { [1.787] }\end{array}$ & $\begin{array}{l}0.5883^{* * *} \\
0.0017[1.801]\end{array}$ & $\begin{array}{l}0.5820 * * * \\
(0.0019)[1.790]\end{array}$ \\
\hline LOGSIZE & + & $\begin{array}{l}0.2083 * * * \\
(<0.0001)[1.232]\end{array}$ & $\begin{array}{l}0.1669 * * * \\
(<0.0001)[1.182]\end{array}$ & $\begin{array}{l}0.1680 * * * \\
(<0.0001)[1.183]\end{array}$ & $\begin{array}{l}0.1508^{* * *} \\
(<0.0001) \\
{[1.163]}\end{array}$ \\
\hline AGE2 & + & $\begin{array}{l}-0.0028 \\
(0.9840) \text { [0.997] }\end{array}$ & $\begin{array}{l}0.0287 \\
(0.8337) \text { [1.029] }\end{array}$ & $\begin{array}{l}0.0360 \\
(0.7918) \text { [1.037] }\end{array}$ & $\begin{array}{l}0.0125 \\
(0.9267) \text { [1.013] }\end{array}$ \\
\hline DMAT & & $\begin{array}{l}0.5015^{* * *} \\
(0.0108)[1.651]\end{array}$ & $\begin{array}{l}0.5701^{* * *} \\
(0.0042)[1.768]\end{array}$ & $\begin{array}{l}0.5240 * * * \\
(0.0054)[1.689]\end{array}$ & $\begin{array}{l}0.5924 * * * \\
(0.0029)[1.808]\end{array}$ \\
\hline DEN & & $\begin{array}{l}0.8608 * * * \\
(<0.0001)[2.365]\end{array}$ & $\begin{array}{l}0.9436 * * * \\
(<0.0001)[2.569]\end{array}$ & $\begin{array}{l}0.9445 * * * \\
(<0.0001)[2.572]\end{array}$ & $\begin{array}{l}0.9632 * * * \\
(<0.0001) \\
{[2.620]}\end{array}$ \\
\hline DHT & & $\begin{array}{l}0.9304 * * * \\
(<0.0001)[2.536]\end{array}$ & $\begin{array}{l}0.8167 * * * \\
(<0.0001)[2.263]\end{array}$ & $\begin{array}{l}0.8292 * * * \\
(<0.0001)[2.291]\end{array}$ & $\begin{array}{l}0.8523^{* * *} \\
(<0.0001) \\
{[2.345]}\end{array}$ \\
\hline DHOT & - & $\begin{array}{l}-0.2793 * * * \\
(0.0235)[0.756]\end{array}$ & $\begin{array}{l}-0.2872 * * * \\
(0.0206)[0.750]\end{array}$ & $\begin{array}{l}-0.2852 * * * \\
(0.0204)[0.752]\end{array}$ & $\begin{array}{l}-0.2875 * * * \\
(0.0204)[0.750]\end{array}$ \\
\hline Chi-Square & & $\begin{array}{l}101.5737^{* * *} \\
(<0.0001)\end{array}$ & $\begin{array}{l}136.2641^{* * *} \\
(<0.0001)\end{array}$ & $\begin{array}{l}135.6040^{* * *} \\
(<0.0001)\end{array}$ & $\begin{array}{l}135.1125^{* * *} \\
(<0.0001)\end{array}$ \\
\hline Number & & 2,028 & 2,028 & 2,028 & 2,028 \\
\hline
\end{tabular}

Cox Proportional Hazard models are estimated using a sample of 2,028 IPOs over the 1986-2003 period. The time to success is measured as the number of months elapsed between the IPO month and the month in which the firm graduated to a senior exchange. The results for each model include the estimated coefficient of each independent variable, the associated $p$-values in parentheses ( ) and the risk ratio between brackets [ ]. NORM1 is a dummy variable equal to 1 if the issuer has no revenues, NORM2 is equal to 1 if the issuer has revenues and earnings per share (EPS) is negative, NORM3 is equal to 1 if the issuer has positive EPS and shareholders' equity is less than \$25 million, NORM12 is equal to 1 if the issuer has negative EPS. PAUDIT is an indicator variable equal to 1 if the firm hired a prestigious audit firm. PUND is an indicator variable equal to 1 if the firm hired a prestigious underwriter firm. LOGTAILLE is defined by the natural logarithm of the post-IPO net assets. AGE2 is a dummy variable equal to 1 if the firm is more than five years old. DMAT is a dummy variable set to 1 if the industry of an issuer is Materials, DEN is a dummy variable set to 1 if the industry of an issuer is Energy and DHT is a dummy variable set to 1 if the issuer produces high-tech products based on the SIC identification and 0 otherwise. DHOT is a dummy variable set to 1 if the IPO occurs during a Hot issue market period and 0 otherwise. 
TABLE 7 Coefficient estimates from multivariate Cox Hazard Models, time to failure and time to success, by industry. MAT means Materials (mining) sector.

\begin{tabular}{lllll}
\hline Variables & $\begin{array}{l}\text { Time to failure } \\
\text { IPO-Model } \\
\text { All sectors but } \\
\text { MAT }\end{array}$ & $\begin{array}{l}\text { Time to failure } \\
\text { IPO- Model } \\
\text { MAT }\end{array}$ & $\begin{array}{l}\text { Time to success } \\
\text { IPO-Model } \\
\text { All sectors but } \\
\text { MAT }\end{array}$ & $\begin{array}{l}\text { Time to success } \\
\text { IPO- Model } \\
\text { MAT }\end{array}$ \\
\hline NORM1 & $1.1560^{* *}$ & $0.3271^{* *}$ & -0.0847 & 0.4664 \\
& $(<0.0001)[3.177]$ & $(0.0394)[1.387]$ & $(0.7757)[0.919]$ & $(0.2104)[1.594]$ \\
NORM2 & $1.1586^{* * *}$ & & 0.1612 \\
& $(<0.0001)[3.185]$ & & $(0.5127)[1.175]$ & \\
NORM3 & $0.7128^{* * *}$ & & 0.0757 & \\
& $(0.0013)[2.040]$ & & $(0.7575)[1.079]$ & \\
PAUDIT & $-0.1618^{*}$ & -0.2393 & $0.5847^{* * *}$ & $0.5374^{*}$ \\
& $(0.0709)[0.851]$ & $(0.1242)[0.787]$ & $(<0.0001)[1.794]$ & $(0.057)[1.712]$ \\
PUND & $-0.2215^{*}$ & -0.2099 & $-0.3988^{* *}$ & -0.5937 \\
& $(0.0750)[0.801]$ & $(0.2633)[0.811]$ & $(0.044)[0.671]$ & $(0.1715)[0.552]$ \\
VBIPO & -0.2849 & & $0.5368^{* * *}$ & \\
& $(0.1374)[0.752]$ & & $(0.0053)[1.710]$ & \\
LOGSIZE & $-0.0784^{* * *}$ & 0.0240 & $0.1444^{* * *}$ & $0.2601^{* * *}$ \\
& $(0.0002)[0.925]$ & $(0.5205)[1.024]$ & $(0.0022)[1.155]$ & $(0.0027)[1.297]$ \\
AGE2 & -0.1514 & $-0.3784^{* *}$ & -0.0332 & 0.2632 \\
& $(0.1333)[0.859]$ & $(0.0151)[0.685]$ & $(0.8284)[0.967]$ & $(0.3661)[1.301]$ \\
DEN & $-0.5423^{* * *}$ & & $0.8992^{* * *}$ & \\
& $(<0.0001)[0.581]$ & & $(<0.0001)[2.458]$ & \\
DHT & -0.0054 & & $0.7879^{* * *}$ & \\
& $(0.9541)[0.995]$ & & $\left.-0.2998^{* * *}\right)$ & -0.2333 \\
DHOT & -0.0272 & -0.1564 & $(0.0365)[0.741]$ & $(0.3524)[0.792]$ \\
& $(0.7434)[0.973]$ & $(0.1698)[0.855]$ & $104.1565^{* * *}$ & $22.7459^{* * *}$ \\
Chi-Square & $203.2994^{* * *}$ & $17.2384^{* * *}$ & $(<0.0001)$ & $(0.0009)$ \\
Number & $(<0.0001)$ & $(0.0084)$ & 1,390 & 638 \\
\hline
\end{tabular}

Cox Proportional Hazard models are estimated using a sample of 2,028 IPOs over the 1986-2003 period. The time to failure is measured as the number of months elapsed between the IPO month and the month in which the firm is delisted from TSXV for negative reasons. The time to success is measured as the number of months elapsed between the IPO month and the month in which the firm graduated to a senior exchange. The results for each model include the estimated coefficient of each independent variable, the associated $p$-values in parentheses ( ) and the risk ratio between brackets [ ]. NORM1 is a dummy variable equal to 1 if the issuer has no revenues, NORM2 is equal to 1 if the issuer has revenues and earnings per share (EPS) is negative, NORM3 is equal to 1 if the issuer has positive EPS and shareholders' equity is less than \$25 million, NORM12 is equal to 1 if the issuer has negative EPS. PAUDIT is an indicator variable equal to 1 if the firm hired a prestigious audit firm. PUND is an indicator variable equal to 1 if the firm hired a prestigious underwriter firm. LOGTAILLE is defined by the natural logarithm of the post-IPO net assets. AGE2 is a dummy variable equal to 1 if the firm is more than five years old. DEN is a dummy variable set to 1 if the industry of an issuer is Energy and DHT is a dummy variable set to 1 if the issuer produces high-tech products based on the SIC identification and 0 otherwise. DHOT is a dummy variable set to 1 if the IPO occurs during a Hot issue market period and 0 otherwise. 
TABLE 8 Summary of our results.

\begin{tabular}{|c|c|c|c|}
\hline \multirow[t]{2}{*}{ Proposition } & \multirow[t]{2}{*}{ Variable } & \multicolumn{2}{|c|}{$\begin{array}{l}\text { Observed significant relation with } \\
\text { propensity to }\end{array}$} \\
\hline & & Fail & Succeed \\
\hline 1 & Firm reports revenues at the IPO & Yes (-) & No \\
\hline 2 & Firm reports positive earnings at the IPO & Yes $(-)$ & No \\
\hline 3 & $\begin{array}{l}\text { Firm is profitable and reports more than } \\
\text { CAN } \$ 25 \text { million in shareholders' equity }\end{array}$ & Yes (-) & No \\
\hline 4 & Level of listing requirement met at the IPO & Yes & No \\
\hline $5 a$ & IPO backed by VCs & No & Yes $(+)$ \\
\hline $5 b$ & Prestigious Auditor involved & Yes (-) & Yes $(+)$ \\
\hline 5c & Prestigious Investment Banker involved & Yes $(-)$ & Yes (-) \\
\hline 6 & Age at the IPO & Yes $(-)$ & Yes $(+)$ \\
\hline 7 & Size at the IPO time & Yes (-) & Yes $(+)$ \\
\hline 8 & Industrial sector influence & Yes, natural resources & Yes \\
\hline 9 & Hot Issue Market at the IPO time & No & Yes $(-)$ \\
\hline
\end{tabular}




\section{REFERENCES}

Audretsch, D. B. and E. E. Lehmann (2005). The Effects of Experience, Ownership, and Knowledge on IPO Survival: Empirical Evidence from Germany. Review of Accounting and Finance 4(4): 13-33.

Beatty, R. and P. Kadiyala (2003). Impact of the Penny Stock Reform Act of 1990 on the Initial Public Offering Market. Journal of Law and Economics 46(2): 517-541.

Berger, A.-N. and G.-F. Udell (1998). The Economics of Small Business Finance: The Roles of Private Equity and Debt Markets in the Financial Growth Cycle. Journal of Banking \& Finance 22(6-8): 613-673.

Bhabra, H. S. and R. H. Pettway (2003). IPO Prospectus Information and Subsequent Performance. The Financial Review 38(3): 369-397.

Bottazzi, L. and M. Da Rin (2002). Venture Capital in Europe and the Financing of Innovative Companies. Economic Policy : A European Forum 17(34): 231-69.

Bottazzi, L. and M. Da Rin (2005). Financing Entrepreneurial Firms in Europe: Facts, Issues, and Research Agenda Venture Capital, Entrepreneurship, and Public Policy. C. Keuschnigg and V. Kanniainen (eds.). Cambridge, MA, MIT Press.: 3-33.

Bradley, D. J., J. W. Cooney, S. D. Dolvin and B. D. Jordan (2006). Penny Stock IPOs. Financial Management 35(1): 5-29.

Burghof, H.-P. and A. Hunger (2004). The Neuer Markt: An (Overly) Risky Asset of Germany's Financial System Advances in Financial Economics. G. Giudici and P. Roosenboom, JAI. Volume 10: 295-327.

Carpentier, C., J.-F. L'Her and J.-M. Suret (2009). Stock Exchange Markets for New Ventures. Forthcoming in Journal of Business Venturing

Carpentier, C., J.-F. L’Her and J.-M. Suret (2008). Does Securities Regulation Constrain Small Business Finance? An Empirical Analysis. Small Business Economics 31(4): 363-377.

Carpentier, C. and J.-M. Suret (2006). Bypassing the Financial Growth Cycle: Evidence from Capital Pool Companies. Journal of Business Venturing 21(1): 45-73.

Carter, R. and S. Manaster (1990). Initial Public Offerings and Underwriter Reputation. The Journal of Finance 45(4): 1045-1067.

Carter, R. B., F. H. Dark and A. K. Singh (1998). Underwriter Reputation, Initial Returns, and the Long-run Performance of IPO Stocks. The Journal of Finance 53(1): 285-311.

Chiu, H.-Y. (2004). Can UK Small Businesses Obtain Growth Capital in the Public Equity Markets? - An Overview of the Shortcomings in UK and European Securities Regulation and Condiderations For Reform. Delaware Journal of Corporate Law 28(3): 933-977.

Chou, T.-K., J.-C. Cheng and C.-C. Chien (2006). Does the Involvement of Expert Intermediaries Improve the Survival Profile of IPO Firms? Evidence from Industry Specialist Auditors and Reputable Venture Capitalists. The Joint 14th PBFEA and 2006 FeAT Conference

Coakley, J., L. Hadass and A. Wood (2007). Post-IPO Operating Performance, Venture Capitalists and Market Timing. Journal of Business Finance \& Accounting 34(9-10): 1423-1446.

Cohn, S. R. (1999). Impact of Securities Laws on Developing Companies: Would the Wright Brothers Have Gotten off the Ground? Journal of Small and Emerging Business Law 3: 315-366.

Cox, D. R. (1972). Regression Models and Life-Tables. Journal of the Royal Statistical Society 34(2): 187-220. 
Dalbor, M. C. and M. J. Sullivan (2005). The Initial Public Offerings of Restaurant Firms: The Case of Industry-Specific Micromarket Capitalization Offerings. Journal of Small Business Management 43(3): 226-242.

Demers, E. A. and P. Joos (2007). IPO Failure Risk. Journal of Accounting Research 45(2): 333371.

Fama, E. F. and K. R. French (1993). Common Risk Factors in the Returns on Stocks and Bonds. Journal of Financial Economics 33(1): 3-56.

Fama, E. F. and K. R. French (2004). Newly Listed Firms: Fundamentals, Survival Rates, and Returns. Journal of Financial Economics 73(2): 229-169.

Field, L. C. and M. B. Lowry (2005). Institutional Versus Individual Investment in IPOs: The Importance of Firm Fundamentals. AFA 2006 Boston Meetings

Gilbert, B. A., P. P. McDougall and D. B. Audretsch (2006). New Venture Growth: A Review and Extension. Journal of Management 32(6): 926-950.

Giudici, G. and P. Roosenboom (2004). The Rise and Fall of Europe's New Stock Markets: Preface. Advances in Financial Economics. G. Giudici and P. Roosenboom, JAI. Volume 10: ix xiv.

Harris, A. D. (2006). The Impact of Hot Issue Markets and Noise Traders on Stock Exchange Listing Standards. University of Toronto Law Review. 56(Summer): 223-280.

Helwege, J. and N. Liang (2004). Initial Public Offerings in Hot and Cold Markets. Journal of Financial and Quantitative Analysis 39(3): 541-569.

Hensler, D. A., R. C. Rutherford and T. M. Springer (1997). The Survival of Initial Public Offerings in the Aftermarket. Journal of Financial Research 20(1): 93-110.

Jain, B. A., N. Jayaraman and O. Kini (2008). The Path-to-profitability of Internet IPO firms. Journal of Business Venturing 2(2): 165-194.

Jain, B. A. and O. Kini (2000). Does the Presence of Venture Capitalists Improve the Survival Profile of IPO Firms? Journal of Business Finance \& Accounting 27(9/10): 1139-1183.

Kim, J. (1999). The Relaxation of Financing Constraints by the Initial Public Offering of Small Manufacturing Firms. Small Business Economics 12(3): 191-202.

Klein, A. and P. S. Mohanram (2006). Economic Consequences of Differences in NASDAQ Initial Listing Standards: The Role of Accounting Profitability. Working Paper, Stern School of Business

Ljungqvist, A. P., T. Jenkinson and W. J. Wilhelm Jr (2003). Global Integration in Primary Equity Markets: The Role of U.S. Banks and U.S. Investors. Review of Financial Studies 16(1): 63-99.

Locke, S. M. and K. Gupta (2008). The Performance of Entrepreneurial Companies Post-listing on the New Zealand Stock Exchange. Venture Capital 10(1): 87-110.

Loughran, T. and J. Ritter (2004). Why Has IPO Underpricing Changed Over Time? Financial Management 33(3): 5-37.

Luft, C. and L. M. Levine (2004). Over the Counter Bulletin Board Exchange: The Impact of Liquidity and Size to Return, Volatility, and Bid/Ask Spread. Journal of Alternative Investments 7(3): 95-106.

Mittoo, U. R. (1992). Perceptions of the Net Benefit of Foreign Listing: Canadian Evidence. Journal of International Financial Management and Accounting 4: 40-62.

Samitas, A. and D. Kenourgios (2005). Entrepreneurship, Small and Medium Size Business Markets and European Economic Integration. Journal of Policy Modeling 27: 363-374.

Schultz, P. (1993). Unit Initial Public Offerings: A Form of Staged Financing. Journal of Financial Economics 34(2): 199-230. 
SEC (2006). Final Report of the Advisory Committee on Smaller Public Companies to the U.S. Securities and Exchange Commission. Report, SEC: Washington DC.

Seguin, P. J. and M. M. Smoller (1997). Share Price and Mortality: An Empirical Evaluation of Newly Listed Nasdaq Stocks. Journal of Financial Economics 45(3): 333-363.

van der Goot T., van Giersbergen N. and M. Botman (2007). What Determines the Survival of Internet IPOs? Applied Economics 39: 1-17.

Weber, J. and M. Willenborg (2003). Do Expert Informational Intermediaries Add Value? Evidence from Auditors in Microcap Initial Public Offerings. Journal of Accounting Research 41(4): 681-720. 